\title{
Eyelid Carcinoma Pathologic Distant Metastasis TNM Finding v8
}

National Cancer Institute

\section{Source}

National Cancer Institute. Eyelid Carcinoma Pathologic Distant Metastasis TNM Finding v8. NCl Thesaurus. Code C140483.

A pathologic finding about one or more characteristics of eyelid carcinoma, following the rules of the TNM AJCC V8 classification system as they pertain to distant metastases. 